\title{
PENGARUH PENAMBAHAN PERASAN PAPRIKA MERAH (Capsicum annuum) DALAM PAKAN TERHADAP TINGKAT KECERAHAN WARNA IKAN KOI (Cyprinus carpio L.)
}

\section{THE INFLUENCE OF ADDITIONAL RED PEPPER (Capsicum annuum) JUICE IN FISH FEED TO KOI FISH'S (Cyprinus carpio L.) COLOR BRIGHTNESS LEVEL}

\author{
Nindya Putriana, Wahju Tjahjaningsih dan Moch. Amin Alamsjah \\ Fakultas Perikanan dan Kelautan Universitas Airlangga \\ Kampus C Mulyorejo - Surabaya, 60115 Telp. 031-5911451
}

\begin{abstract}
Koi fish (Cyprinus carpio L.) is high economical fish and has some type of color and pattern on its body. Koi fish (C. carpio L.) is particularly prone to unstable water quality so the fish with prime condition is very limited. To get the fish with the prime condition required several supporting factors such as the genetic, environment and nutritional feed. In this research the used of red pepper (Capsicum аппиит) juice as an additional ingredient in fish feed.

The aim of this research is to know about the influence of additional red pepper juice $(C$. annuиm) to the brightness of the color of koi fish (C. carpio L.) and the optimal concentration. There are six treatment used in this research, which are treatment A just given by pelet as a control, B treatment is adding red pepper juice by concentration of $1 \%, \mathrm{C}$ by concentration of $3 \%$ and $\mathrm{D}$ by concentration of $5 \%$. $\mathrm{E}$ treatment is adding carrot juice by concentrations of $4.5 \%$ and $\mathrm{F}$ treatment is adding astaxanthin by concentration of $1 \%$. Each treatment given to fish with the level of color brightness that has score 2.

The result of color scoring tested by experiment description method that in the end of research on A treatment (control) didn't increase with the same score 2. B treatment (red pepper 1\%) increased from score 2 to score 3 started from day 28. C treatment (red pepper 3\%) increased from score 2 to score 3 started from day 21. D treatment (red pepper 5\%) increased from score 2 to score 4 started from day 21. E treatment (carrot 4,5\%) increased from score 2 to score 4 started from day 28. F treatment (astaxanthin $1 \%$ ) increased from score 2 to score 4 started from day 21.
\end{abstract}

Keywords : nindya, pepper, koi, brightness

\section{Pendahuluan}

Ikan koi (C. carpio L.) merupakan ikan hias ekonomis tinggi dimana masih termasuk dalam kerabat ikan mas. Ikan koi memiliki warna tubuh yang berwarna - warni dengan berbagai jenis dan pola (Suryani, 2006). Menurut Agus (2002), kriteria pemilihan ikan koi yang baik adalah bentuk tubuh ideal tidak melebar, tidak bengkok tulang punggungnya, warna cemerlang dan kontras tanpa ada gradasi warna atau bayangan, gerakan ikan tenang namun gesit serta tidak menyendiri dan sakit. Beberapa faktor yang mempengaruhi kecerahan warna pada ikan koi adalah faktor genetik, lingkungan dan nutrisi pakan.

Penelitian ini menggunakan metode penambahan bahan pakan alami yaitu paprika merah ( $C$. annuum) sebagai peningkat kecerahan warna ikan koi. Menurut Aysun et al (2010), pigmen alami yang mengandung unsur caroteenoid dapat meningkatkan kecerahan warna pada ikan koi yang dipelihara. Paprika merah mengandung pigmen karotenoid yang mampu meningkatkan warna merah sampai coklat sehingga pada ikan koi dapat memperjelas kecerahan warnanya (Lesmana, 2004). Selain karotenoid paprika merah juga mengandung vitamin $\mathrm{C}$, vitamin $\mathrm{E}$ dan lycopene yang dapat membantu proses peningkatan kecerahan warna ikan (Noverina, 2009).

Tujuan dari penelitian ini adalah untuk mengetahui pengaruh penambahan perasan paprika merah (C. annuum) dalam pakan terhadap peningkatan kecerahan warna ikan koi (C. carpio L.) serta mengetahui konsentrasi optimal perasan yang dapat meningkatkan kecerahan warna terbaik.

\section{Materi dan Metode \\ Waktu dan Tempat}

Penelitian ini dilaksanakan di Laboratorium Pendidikan Fakultas Perikanan dan Kelautan Universitas Airlangga pada bulan November 2011.

Materi Penelitian

Alat Penelitian 
Peralatan yang digunakan dalam penelitian ini terdiri dari 24 buah akuarium ukuran $(30 \times 18 \times 20) \mathrm{cm}$, enam buah stoples plastik ukuran sedang, dua buah aerator, selang aerasi, batu aerasi, gelas ukur, kertas $\mathrm{pH}$, saringan, refraktometer, timbangan, ember, sprayer dan spons.

\section{Bahan Penelitian}

Bahan yang digunakan dalam penelitian ini terdiri dari buah paprika merah (C. annuum) yang diperoleh dari pasar tradisional Wonokromo dan swalayan di daerah Wiyung, wortel (D. carota) yang diperoleh dari pasar tradisional Wiyung, 24 ekor ikan koi (C. carpio L.) yang diperoleh dari pasar ikan Gunungsari dengan ukuran panjang total $5-10 \mathrm{~cm}, 1 \mathrm{~kg}$ pelet ikan merek Takari, sabun cuci, 3 gram astaxanthin dan 100 gram kalium permanganat.

\section{Metode Penelitian}

Penelitian ini bersifat eksperimental, yang digunakan untuk mengetahui pengaruh variabel tertentu terhadap suatu kelompok dalam kondisi yang terkontrol. Rancangan percobaan yang digunakan pada penelitian ini adalah Rancangan Acak Lengkap (RAL). RAL digunakan bila media atau bahan percobaan seragam (Kusriningrum, 2008). Penelitian ini terdiri dari enam perlakuan dengan empat kali ulangan. Perlakuan yang diberikan adalah perlakuan A (kontrol), perlakuan B (paprika 1\%), perlakuan C (paprika $3 \%$ ), perlakuan D (paprika 5\%), perlakuan $\mathrm{E}$ (wortel 4,5\%) dan perlakuan $\mathrm{F}$ (astaxanthin $1 \%)$.

\section{Prosedur Kerja}

Paprika merah ( $C$. annuum) dicuci, dibuang tangkainya dan diproses menggunakan blender kemudian diambil perasannya. Perasan paprika merah tersebut diencerkan agar mendapatkan konsentrasi $1 \%, 3 \%$ dan $5 \%$. Wortel dicuci kemudian dihaluskan menggunakan blender dan diambil perasannya. Konsentrasi perasan wortel yang digunakan sebagai pembanding bahan alami adalah 4,5\% (Massie, 2007). Astaxanthin diencerkan dengan akuades sehingga menghasilkan konsentrasi $1 \%$ yang kemudian dicampurkan ke dalam pakan. Pelet yang digunakan adalah pelet padat terapung ukuran $\mathrm{S}$ yang memiliki kandungan protein $30 \%$ sesuai dengan kebutuhan harian ikan koi. Menurut Agus dkk. (2002), kebutuhan protein harian ikan koi muda adalah $30 \%$.

Ikan koi (C. carpio L.) berukuran 5-10 $\mathrm{cm}$, dengan beberapa jenis warna berbeda dikelompokkan warnanya untuk setiap perlakuan. Ikan diaklimatisasi terlebih dahulu selama 15 menit untuk membantu proses adaptasi ikan di lingkungan yang baru (Agus dkk., 2002). Ikan yang telah diaklimatisasi dibagi di setiap akuarium dengan jumlah satu ekor/akuarium dengan kelompok perlakuan yang telah ditentukan. Penempatan satu ekor ikan setiap perlakuan ditujukan agar penyerapan pakan maksimal dan tidak terjadi persaingan dalam proses pemberian pakan.

\section{Parameter Pengamatan}

Parameter utama yang diamati adalah perubahan warna tubuh ikan koi selama perlakuan. Penentuan kecerahan warna ikan di setiap perlakuan dihitung menggunakan skoring warna setiap minggu dari awal hingga akhir penelitian, skor empat adalah warna dengan tingkat kepekatan warna paling tinggi. Skor tiga untuk kepekatan warna tinggi, skor dua untuk kepekatan warna sedang dan skor satu untuk kepekatan warna yang rendah. Kepekatan warna dilihat dari kesesuaian dengan truematch colour pada diagram warna komputer dengan cara membandingkan warna ikan dengan kertas diagram warna (Massie, 2007).

Parameter penunjang meliputi kualitas air antara lain suhu, $\mathrm{pH}$ dan salinitas. Pengukuran suhu menggunakan termometer, $\mathrm{pH}$ dengan kertas $\mathrm{pH}$, dan salinitas menggunakan refraktometer serta dissolve oxygen (DO) menggunakan DO meter. Pengukuran dilakukan setiap minggu pada pagi hari untuk menambah tingkat ketepatan data. Pengukuran dilakukan sebanyak empat kali, yaitu pada awal perlakuan, minggu kedua, minggu ketiga, dan minggu keempat. Selain kualitas air penghitungan survival rate (SR) juga dilakukan pada akhir perlakuan untuk mengetahui tingkat keamanan penggunaan bahan penelitian.

\section{Anaisis Data}

Data yang diperoleh dianalisis dengan menggunakan metode deskriptif yaitu metode yang bermaksud untuk memaparkan tentang situasi atau kejadian tertentu (Suryabrata, 1987 dalam Putra, 2012).

\section{Hasil dan Pembahasan}

\section{Kecerahan Warna Ikan Koi}

Pengamatan perubahan warna ikan koi (C. carpio L.) diamati setiap tujuh hari sekali selama 35 hari dengan menggunakan diagram warna truematch color yang telah diberi nilai (skor 1 - 4). Pengamatan warna pada tubuh ikan koi dilihat mulai dari ujung kepala hingga ujung ekor termasuk bagian sirip ikan koi. Pada awal penelitian, warna ikan koi semua 


\section{Skor}

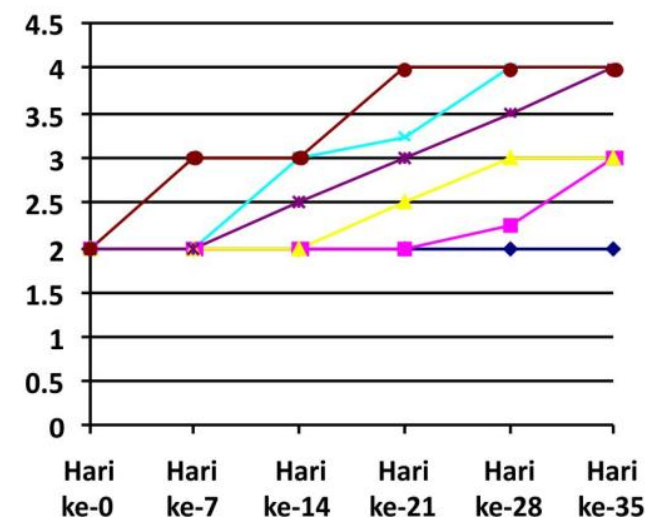

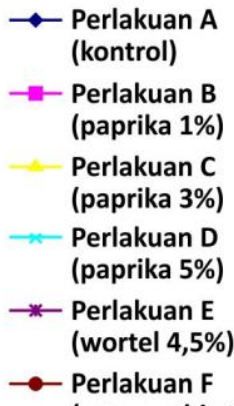

(astaxanthin 1\%)

Gambar 1. Grafik peningkatan kecerahan warna ikan koi

perlakuan memiliki nilai yang sama yaitu skor 2. Pada akhir penelitian yaitu hari ke-35, perlakuan A (kontrol) mendapat skor 2, perlakuan B (paprika 1\%) mendapat skor 3, perlakuan C (paprika 3\%) mendapat skor 3, perlakuan D (paprika 5\%) mendapat skor 4, perlakuan E (wortel 4,5\%) mendapat skor 4 dan perlakuan F (astaxanthin 1\%) mendapat skor 4. Data skoring warna masing - masing perlakuan pada penelitian selama 35 hari dapat dilihat pada Tabel 1 dan grafik peningkatan kecerahan warna ikan koi (C. carpio L.) dapat dilihat pada Gambar 1.

\section{Tingkat Kelangsungan Hidup Ikan Koi (Cyprinus carpio L.)}

Tingkat kelangsungan hidup ikan koi $(C$. carpio L.) adalah presentasi jumlah ikan yang mampu hidup hingga akhir penelitian yaitu hari ke-35. Dari 24 ekor ikan koi (C. carpio L.) yang digunakan sebagai bahan penelitian, semua ikan berhasil hidup sampai pada hari terakhir penelitian sehingga presentasi survival rate (SR) ikan koi (C. carpio L.) adalah $100 \%$.

\section{Kualitas Air}

Parameter kualitas air dalam media penelitian yang diamati adalah $\mathrm{pH}$, dissolve oxygen (DO) dan suhu. Pengukuran suhu dilakukan setiap hari pada pagi, siang dan sore hari sedangkan pengukuran $\mathrm{pH}$ dilakukan sekali setiap harinya pada waktu pagi hari begitu juga dengan pengukuran DO. Dari hasil pengukuran tersebut didapatkan bahwa rata - rata suhu berkisar antara $26^{\circ}-28^{\circ} \mathrm{C}$, rata - rata $\mathrm{pH}$ sebesar 6,5 - 7 dan rata - rata DO adalah 5 ppm.
Perubahan kecerahan warna ikan koi $(C$. carpio L.) dipengaruhi oleh beberapa faktor seperti genetik, lingkungan dan nutrisi pada pakan. Dalam penelitian ini faktor yang ditekankan dalam peningkatan warna ikan koi (C. carpio L.) adalah faktor nutrisi. Menurut Noverina (2009), paprika merah (C. annuum) memiliki kandungan nutrisi berupa likopein, caroteenoid dan vitamin $\mathrm{C}$ yang dapat dijadikan sebagai nutrisi tambahan pada peningkatan kecerahan warna pada ikan.

Selama 35 hari penelitian, perlakuan perasan paprika merah (C. annuum) yang ditambahkan menunjukkan adanya peningkatan warna yang diharapkan. Pada pemberian perasan paprika merah konsentrasi $1 \%$ (perlakuan B) pada hari ke-35 kecerahan warna semua ikan mencapai skor 3 dan pada pemberian perasan paprika merah konsentrasi 3\% (perlakuan $\mathrm{C}$ ) pada hari ke-28 kecerahan warna semua ikan juga mencapai skor 3 , namun pada pemberian perasan paprika merah konsentrasi 5\% (perlakuan D) kecerahan warna semua ikan mencapai skor 4 pada hari ke-28. Hal ini menunjukkan bahwa pada konsentrasi $5 \%$, kandungan zat seperti cerra-carotene, likopen dan vitamin $\mathrm{C}$ pada perasan paprika merah sudah cukup untuk meningkatkan warna sampai ke skor 4. Menurut Levetin and McMahon (1999), carotenoid merupakan salah satu zat pembentuk vitamin A yang berfungsi sebagai zat pembentuk pigmen warna pada lapisan dermis ikan sehingga dengan penambahan perasan paprika merah dapat menambah jumlah asupan provitamin A dalam proses pembentukan pigmen warna pada ikan koi (C. carpio L.). 
Tabel 1. Hasil Skoring Warna Tubuh Ikan Koi (C. carpio L.)

\begin{tabular}{|c|c|c|c|c|c|c|c|}
\hline \multirow{2}{*}{ Ulangan } & \multirow{2}{*}{ Perlakuan } & \multicolumn{6}{|c|}{ Skor } \\
\hline & & $\mathrm{H}-0$ & $\mathrm{H}-7$ & H-14 & H-21 & H-28 & H-35 \\
\hline 1 & \multirow{5}{*}{$\begin{array}{c}\text { A } \\
\text { (kontrol) }\end{array}$} & 2 & 2 & 2 & 2 & 2 & 2 \\
\hline 2 & & 2 & 2 & 2 & 2 & 2 & 2 \\
\hline 3 & & 2 & 2 & 2 & 2 & 2 & 2 \\
\hline 4 & & 2 & 2 & 2 & 2 & 2 & 2 \\
\hline $\begin{array}{c}\text { Rata - } \\
\text { Rata }\end{array}$ & & 2 & 2 & 2 & 2 & 2 & 2 \\
\hline 1 & \multirow{5}{*}{$\begin{array}{c}\mathrm{B} \\
\text { (paprika } \\
1 \%)\end{array}$} & 2 & 2 & 2 & 2 & 2 & 3 \\
\hline 2 & & 2 & 2 & 2 & 2 & 3 & 3 \\
\hline 3 & & 2 & 2 & 2 & 2 & 2 & 3 \\
\hline 4 & & 2 & 2 & 2 & 2 & 2 & 3 \\
\hline $\begin{array}{c}\text { Rata - } \\
\text { Rata }\end{array}$ & & 2 & 2 & 2 & 2 & 2,25 & 3 \\
\hline 1 & \multirow{5}{*}{$\begin{array}{c}\mathrm{C} \\
\text { (paprika } \\
3 \%)\end{array}$} & 2 & 2 & 2 & 3 & 3 & 3 \\
\hline 2 & & 2 & 2 & 2 & 2 & 3 & 3 \\
\hline 3 & & 2 & 2 & 2 & 2 & 3 & 3 \\
\hline 4 & & 2 & 2 & 2 & 3 & 3 & 3 \\
\hline $\begin{array}{c}\text { Rata - } \\
\text { Rata }\end{array}$ & & 2 & 2 & 2 & 2,5 & 3 & 3 \\
\hline 1 & \multirow{5}{*}{$\begin{array}{c}\mathrm{D} \\
\text { (paprika } \\
5 \%)\end{array}$} & 2 & 2 & 3 & 3 & 4 & 4 \\
\hline 2 & & 2 & 2 & 3 & 3 & 4 & 4 \\
\hline 3 & & 2 & 2 & 3 & 4 & 4 & 4 \\
\hline 4 & & 2 & 2 & 3 & 3 & 4 & 4 \\
\hline $\begin{array}{c}\text { Rata - } \\
\text { Rata }\end{array}$ & & 2 & 2 & 3 & 3,25 & 4 & 4 \\
\hline 1 & \multirow{5}{*}{$\begin{array}{c}\mathrm{E} \\
\text { (wortel } \\
4,5 \% \text { ) }\end{array}$} & 2 & 2 & 2 & 3 & 3 & 4 \\
\hline 2 & & 2 & 2 & 2 & 3 & 3 & 4 \\
\hline 3 & & 2 & 2 & 3 & 3 & 4 & 4 \\
\hline 4 & & 2 & 2 & 3 & 3 & 4 & 4 \\
\hline $\begin{array}{c}\text { Rata - } \\
\text { Rata }\end{array}$ & & 2 & 2 & 2.5 & 3 & 3.5 & 4 \\
\hline 1 & \multirow{5}{*}{$\begin{array}{c}\mathrm{F} \\
\text { (astaxanthin } \\
1 \%)\end{array}$} & 2 & 3 & 3 & 4 & 4 & 4 \\
\hline 2 & & 2 & 3 & 3 & 4 & 4 & 4 \\
\hline 3 & & 2 & 3 & 3 & 4 & 4 & 4 \\
\hline 4 & & 2 & 3 & 3 & 4 & 4 & 4 \\
\hline $\begin{array}{c}\text { Rata - } \\
\text { Rata }\end{array}$ & & 2 & 3 & 3 & 4 & 4 & 4 \\
\hline
\end{tabular}

Kandungan zat lain dalam paprika merah yaitu likopen memiliki beberapa fungsi yang dapat meningkatkan kecerahan warna pada ikan yaitu memberikan efek pigmentasi terutama warna merah, melindungi lapisan dermis dari sinar UV dan merupakan antioksidan kuat untuk mengurangi kerusakan sel pada tubuh (Noverina, 2009). Sedangkan vitamin C dapat mendegradasi radikal bebas yang terlepas saat pembentukan adenosine triphospphate (ATP) di dalam mitokondria sehingga proses metabolik pembentukan sel pigmen tidak terhambat dan pigmen warna tersebut lebih cepat terbentuk (Levetin and McMahon, 1999).

Secara berurutan dimulai dari penyerapan carotenoid dalam tubuh ikan, carotenoid membentuk provitamin A yang kemudian diubah oleh organ tubuh ikan (hati) menjadi vitamin A. Vitamin A tersebut pada lapisan dermis mulai membentuk pigmen warna. Bersamaan dengan penyerapan likopen dalam tubuh, likopen menambah efek pigmentasi pada sel warna dan melindungi lapisan sel dari sinar UV untuk mempertahankan sel dari kerusakan (Harrison, 2011). Penyerapan vitamin $C$ dalam tubuh ikan yang direaksikan oleh beberapa reaksi enzimatik menghasilkan pemecahan protein dalam jumlah tertentu sehingga mempercepat pengeluaran sel warna yang telah terbentuk di lapisan dermis. Sel warna yang telah keluar dilapisi oleh vitamin $\mathrm{C}$ yang berfungsi sebagai 
antioksidan sehingga mampu mempertahankan sel warna tersebut dari kerusakan akibat radikal bebas (Aguirre and May, 2010).

Jika dibandingkan dengan penambahan perasan wortel (D. carrota) konsentrasi $4,5 \%$ pada perlakuan $\mathrm{E}$, penambahan perasan paprika merah konsentrasi 5\% lebih efisien karena mampu meningkatkan warna ikan sampai dengan skor 4 dalam waktu 28 hari, sedangkan perlakuan yang ditambahkan wortel baru pada hari ke-35 mampu meningkatkan warna sampai ke skor 4. Hal tersebut wajar karena menurut Fitriyah (2010), kandungan vitamin C pada paprika merah hampir 27 kali lipat dari wortel. Dalam setiap 100 gram daging buah paprika merah mengandung $190 \mathrm{mg}$ vitamin $\mathrm{C}$, sedangkan wortel hanya mengandung $7 \mathrm{mg}$ saja.

Pada perlakuan $\mathrm{F}$ yang ditambah astaxanthin 1\% mampu menaikkan kecerahan warna ikan koi ke skor 4 pada hari ke-21 untuk semua ikan, sedangkan perlakuan D yang ditambahkan perasan paprika merah 5\% mampu menaikkan kecerahan warna ikan koi ke skor 4 pada hari ke-21 namun tidak semuanya naik pada hari tersebut. Tingkat kecerahan warna ikan koi pada perlakuan D (paprika 5\%) dapat mencapai skor 4 untuk semua ikan baru terlihat pada hari ke-28. Hal ini disebabkan karena struktur dari rantai astaxanthin yang berbeda sehingga lebih cepat diserap oleh tubuh ikan dibandingkan dengan carotenoid yang ada dalam perasan paprika merah (Aysun et al., 2010). Perbedaan rantai karbon antara astaxanthin dengan beta-caroteen terletak pada kedua ujung rantai. Pada ujung rantai astaxanthin terdapat hydroxyl $\mathrm{O}$ dan hydroxyl $\mathrm{OH}$ yang lebih berpengaruh kinerjanya dibandingkan dengan beta-caroteen (Capelli and Cysewski, 2007).

Selain itu astaxanthin tidak seperti kebanyakan carotenoid yang berubah menjadi vitamin A atau retinol yang pada dasarnya akan menjadi racun jika terkonsumsi secara berlebihan (Mortensen and Skibsted, 1997). Astaxanthin memiliki fungsi biosintetik yang sama dengan carotene karena memiliki polyene chain yang sama kemampuannya dalam menangkal radikal bebas. Apabila carotene bekerja dari dalam jaringan lipid, sebaliknya astaxanthin bekerja dengan cara menyebar dari dalam jaringan lipid hingga ke bagian polar head jaringan lipid. Hal tersebutlah yang menyebabkan proses pengeluaran pigmen warna oleh astaxanthin lebih cepat daripada carotene (Capelli and Cysewski, 2007).

Faktor kualitas air juga memegang peranan penting dalam peningkatan kecerahan warna ikan (Bachtiar dan Tim Lentera, 2004).
Menurut Agus dkk. (2002), suhu perairan yang optimal bagi pertumbuhan ikan koi berkisar antara $15^{\circ}-25^{\circ} \mathrm{C}$ dengan $\mathrm{pH}$ berkisar antara $6,5-8,5$. Suhu pada media air selama penelitian berkisar antara $26^{\circ} \mathrm{C}-28^{\circ} \mathrm{C}$ dan $\mathrm{pH}$ berkisar antara 6,5 - 7. Kondisi suhu yang lebih tinggi tersebut mengakibatkan proses adaptasi ikan lebih lama sehingga penelitian baru dapat dimulai setelah nafsu makan ikan menjadi normal. Pengukuran dissolve oxygen (DO) dilakukan sekali dalam sehari. Hasil pengukuran DO setiap hari sama dengan kriteria kualitas air yang dibutuhkan yaitu sebesar 5 ppm. Setiap akuarium menggunakan sistem aerasi tambahan yang telah diatur sehingga jumlah oksigen dari aerator yang dikeluarkan sama.

\section{Kesimpulan}

Penambahan perasan paprika merah (C. annuum) dalam pakan dapat meningkatkan kecerahan warna pada ikan koi (C. carpio L.) Konsentrasi perasan paprika merah (C. annuum) yang dapat meningkatkan kecerahan warna ikan koi ( $C$. carpio L.) sampai skor empat dalam waktu 28 hari adalah 5\%. Untuk meningkatkan kecerahan warna ikan koi (C. carpio L.) sebaiknya menambahkan perasan paprika merah (C. annuum) ke dalam pakan ikan. Sebaiknya penambahan perasan paprika merah $(C$. annuиm) dalam pakan tidak lebih dari konsentrasi 5\% karena pada penelitian terdahulu penambahan perasan paprika merah konsentrasi $7 \%$ dan $10 \%$ mengakibatkan ikan sampel mati

\section{Daftar Pustaka}

Aguirre, R. and J.M. May. 2008. Inflammation in The Vascular Bed, Importance of Vitamin C. Pharmacology and Therapeutics 119 (2008). 96 - 103.

Agus, G.T.K., Agus K.A., A. Dianawati, Dipo U.T., E.S. Irawan, K. Miharja, L. Gusyadi, Luluk A.M., Maman N., P.S. Karno, P. Dachlan, Udin S., Ujang J.M., T. Yana dan Y. Sastro. 2002. Koi. PT AgroMedia Pustaka. Tangerang. Hal $23-46$

Aysun, K., Y. Durmaz and M. Hekimoglu. 2010. Effect of Natural Pigment Source on Colouration of Cichlid (Cichlasoma severum sp. Heckel, 1840). Journal of Animal and Veterinary Advances 9 (3). $566-569$.

Bachtiar, Y. dan T. Lentera. 2004. Budidaya Ikan Hias Air Tawar untuk Eksport. AgroMedia Pustaka. Tangerang. Hal $74-81$ 
Capelli, B. and G. Cysewski. 2007. Natural Astaxanthin : King of Carotenoid. Cyanotech Corporation. USA. $4-19$.

Fitriyah, Zakiatul. 2010. Gizi dalam Kesehatan Reproduksi Paprika. Kementrian Kesehatan Republik Indonesia. Banjarmasin. 1 - 10.

Harrison, E.H. 2011. Mechanism Involved in The Intestinal Absorption of Dietary Vitamin A and Provitamin A Carotenoids. Biochemica et Biophysica Acta 1821 (2012). 70 - 77.

Kusriningrum. 2008. Perancangan Percobaan. Universitas Airlangga Surabaya. hal $23-24$

Lesmana, D.S. 2004. Agar Ikan Hias Cemerlang. Penebar Swadaya. Bogor. hal 32 - 43.Levetin, E. and K. McMahon. 1999. Plants and Society. The Mc Graw-Hill Companies. United State of Amerika. Page 166 - 167

Levetin, E. and K. McMahon. 1999. Plants and Society. The Mc Graw-Hill Companies. United State of Amerika. Page 166 - 167
Massie, N.C. 2007. Pengaruh Penambahan Wortel (Duscus carrota L.) dengan Beberapa Metode Pengolahan pada Pakan Terhadap Peningkatan Warna Biru Tubuh Lobster Air Tawar Red Claw (Cherax quadricarinatus). Skripsi. Fakultas Kedokteran Hewan Universitas Airlangga. Surabaya. hal $10-54$

Mortensen, A. and L. H. Skibsted. 1997. Importance of carotenoid structure in radical scavenging reactions. Journal Agric Food Chemical 45 (8): 2970 2977

Noverina, A. 2009. Paprika Cabai Manis Kaya Antioksidan. Nirmala Megazine. Januari 2009 : 1 . hal 2

Putra, A. S. 2012. Pengaruh Penggunaan Substrat yang Berbeda Terhadap Kelangsungan Hidup dan Pertumbuhan Juwana Kepiting Bakau (Scylla paramamosain). Skripsi. Fakultas Perikanan dan Kelautan Universitas Airlangga. Surabaya. hal 24

Suryani. 2006. Budidaya Ikan Hias. PT. Intan Sejati. Klaten. hal $22-26$. 